\title{
Texting the Future in Belgium and Québec: Present matters*
}

\begin{abstract}
This study investigates the variation in the expression of Future Temporal Reference in text messages in Belgian and Québecois French. Three variants are considered: the Futurate Present, the Synthetic Future and the Analytic Future. The results of multivariate analyses show that the use of the Futurate Present does not appear to be subject to dialectal variation: both communities use this variant at similar rates and the use of the variant is constrained by the same linguistic factors. The two dialects show differences in their choice of the Synthetic vs the Analytic Future. Unlike Québecois French, Belgian French strongly favours the Synthetic Future. The two dialects also differ with respect to the linguistic constraints in effect. Our analysis shows the need to explore the relationship between variants, and to distinguish between Covert $\mathrm{T}$
\end{abstract}

* Acknowledgements. 
(realized as Present tense) and Overt T (either Synthetic or Analytic Future). Our results point toward the hybrid nature of text messages: while our results show patterns of use in line with oraVconversational corpora as reflected by the dialectal variation observed, text messages are not exempt from the influence of written French, as shown by the use of Synthetic Future forms in affirmative sentences in the Québec corpus.

Keywords: Synthetic Future, Analytic Future, Inflected Future, Periphrastic Future, Québec French, Belgian French, text messages, SMS 


\section{Introduction}

While spoken French has been an important focus of variationist sociolinguistic inquiries, there is a pressing need to explore linguistic variables in other contexts, particularly in relation to the supposed innovative effect of new media technology on language. As we will see, these means of expression provide new sources of data to explore the vernacular.

French text messages offer a great opportunity to study variation. First, because written French is so different from spoken French, this language is an ideal candidate to evaluate Crystal's (2011) claim that text messages are truly a hybrid form between writing and speech. Unlike written Standard French, which is highly codified and stable, text messages constantly change. Their distinctive features ${ }^{1}$ include abbreviations, truncations, dialectal traits and numerous features associated with speech, as shown by the following example from the Belgium corpus.

(1) Vwala c fê mnt $\mathrm{V}$ me conecT surmsn pr kil se deco Voilà c'est fait maintenant vais me connecter sur MSN pour qu'il se déconnecte

é i sora+se reco. VENGEANCE. jtexplikrè $2 \mathrm{~m} 1$ et il saura plus se reconnecter. VENGEANCE. Je t'expliquerai demain » 'Well it's done now, I'm going to connect to MSN so he is going to disconnect and he won't be able to reconnect. REVENGE. I'll explain

${ }^{1}$ See Fairon et al. (2006), Labeau (2014), Blondeau, Tremblay and Drouin (2014) for a more detailed account of frequent features of French text messages. 
tomorrow'

(BG, user 69)

Example (1) shows many instances of abbreviations ( $\underline{\mathrm{c}}$ for $\underline{\mathrm{c} \text { 'est }}, \underline{\mathrm{mnt}}$ for

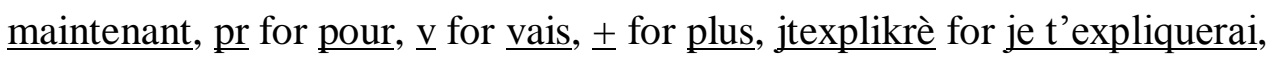
$\underline{2 \mathrm{ml}}$ for demain; one case of truncation ( $\underline{\text { reco }}$ for $\underline{\text { reconnecter}}$; the use of nonstardard orthography (vwala for voilà, fề for fait, conecT for connecter, kil for qu'il, é for et, sora for saura. Other features include the omission of the first person pronoun je (obligatory in both spoken and written French), and phonetic characters (letters as in conecT and numbers as in $2 \mathrm{~m} 1$ ). In addition, example (1) contains many features of spoken French. Some of these features are

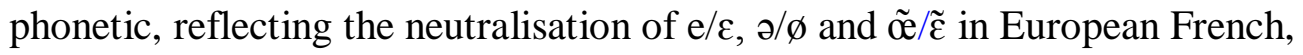

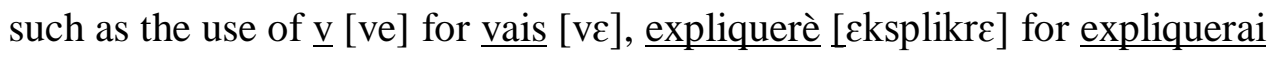

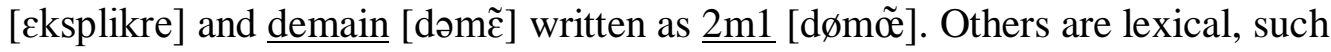
as the use of savoir instead of pouvoir, a case of variation well attested in Belgium. The fact that text messages include dialectal traits is an important feature indicating that text messages reflect speech, rather than written Standard French.

In this paper, we complement previous research on computer-mediated communication by providing a variationist analysis of Future Temporal Reference (FTR) in two corpora of text messages (SMS) from Belgium (Fairon, 
Klein and Paumier, 2006) and Québec (Langlais, Drouin, Paulus, Rompré

Brodeur and Cottin, 2012) $)^{23}$.

Over the last 50 years, numerous analyses of large oral corpora have documented both social and regional variation in the use of the FTR variable.

The three main variants involved are the Synthetic Future, the Analytic Future and the Futurate Present. ${ }^{4}$ Example (1) illustrates the use of the Analytic (v me

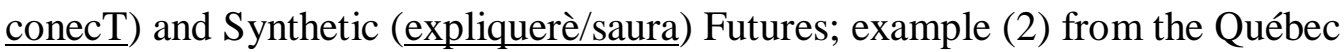
corpus illustrates the use of the Futurate Present.

(2) Ben javais p-e de koi mais je ten reparle tentot Bien j'avais peut-être de quoi mais je t'en reparle tantôt

'Well I had planned something but I'll talk to you later'

(QC, user 112314 )

${ }^{2}$ It must be noted that the Belgian data was collected in 2004, and the Canadian data in 2009. Given the speed of technological developments (e.g. spread of predictive keyboards) in that period, an impact on SMS writing cannot be excluded. However, given the morphosyntactic nature of the variable, there are no reasons to expect such technological changes to impact the FTR variable, with the exception of the spelling of each variants (non-standard orthography and phonetic and the use of phonetic characters).

${ }^{3}$ An anonymous reviewer notes that one of the limitations of the study pertains to the possibility of language change between the years when each dataset was collected and the fact that the current study cannot account for language change. While we cannot exclude the possibility of language change, and in fact Lindschouw (2011) has shown that the Synthetic Future is slowly being replaced by the Analytic Future, the two datasets are close enough in time to allow for dialectal comparison.

${ }^{4}$ In this paper, we use the term Synthetic Future for what other authors call Inflected or Simple Future, and we use Analytic Future for what is often called Periphrastic or Near Future. 
There are a number of reasons to study FTR in French text messages. First, there is an important difference between spoken French and written French (Standard): written French largely favours the use of Synthetic Future (Lesage, 1991; Lesage and Gagnon, 1992; Waugh and Bahloul, 1996; Wales 2002), while colloquial spoken French generally favours the use of Analytic Future as demonstrated in numerous variationist analyses starting with Emirkanian and Sankoff 1985). This quantitative difference is useful to establish whether text messages pattern with spoken or written French, and thus assess the alleged hybridity of text messages. Second, the three variants are not stigmatized in spoken French. Consequently, texters are not likely to be socially aware of their choice of variants, which increases the likelihood that text messages truly reflect their unmonitored use of the three FTR variants. Third, because mobile phones are used for planning events, all three variants are frequent in text messages, including the Futurate Present, which has often been excluded from studies based on its rarity in semi-directed interviews. The frequent use of the Futurate Present in text messages allows us to describe the linguistic factors governing its distribution, and assess its role in the variation. Finally, most studies of FTR in Canadian French have been anchored in the notion of speech community and have provided information about the use of FTR in one community at a time (with the exception of Comeau, 2016). Our 
comparative study of text messages from Belgium and Québec departs from this tradition. The comparative sociolinguistic methodology used in the present study provides a more comprehensive understanding of the variable, and takes dialectal variation into account.

By comparing text messages in two varieties of French, this paper makes several contributions to the literature. Firstly, we contribute to the debate on the nature of computer-mediated communication by providing empirical evidence that text messages pattern with speech. Our results demonstrate how, as a hybrid form of communication, text messages share many features with ora $/$ conversational data, while to some extent being influenced by written French. Secondly, while many previous studies have excluded the Futurate Present from the analysis, our study reintegrates this variant and shows its role in the variation. We show that, while the use of the Futurate Present is not subject to dialectal variation, the two dialects show differences in their choice of the Synthetic Future vs the Analytic Future. Such differences are illustrated not only in term of the frequency of the variants but also in term of the linguistic constraints on variation. Finally, our study highlights the importance of widening the types of corpora, by contrasting the conversational nature of text messages with semi-directed interviews. 
The discussion is organized as follows. In the next section of the paper, we offer a brief overview of FTR in French, with particular attention to varieties and variants studied, types of corpora, and factors favouring the use of the variants. Section 3 addresses the challenges associated with the description of the variable context. Section 4 is devoted to the methodology (corpora, exclusions, coding procedures, and statistical analyses). We report the results of our analysis in section 5. Finally, section 6 discusses the interpretation of our results: we first explore the relationship between variants, morphologically marked (the analytic and synthetic futures) or not (the Futurate Present), and conclude with a discussion of the conversational nature of text corpora.

\section{FTR in French}

\subsection{Overview of varieties and variants studied}

The use of FTR has generated a lot of attention in variationist sociolinguistics and has been widely researched across many varieties of spoken French. Since Deshaies and Laforge (1981), the variable has been studied extensively in a large number of dialects of Canadian French: Acadian French (Chevalier, 1996; King and Nadasdi, 2003; Comeau, 2011, 2015), Québec French (Deshaies and Laforge, 1981; Emirkanian and D. Sankoff, 1985; Zimmer, 1994; Blondeau, 2006; Wagner and G. Sankoff, 2011; G. Sankoff, Evans Wagner and Jensen, 2012) Ontario French (Grimm, 2010, 2015; 
Grimm and Nadasdi, 2011) and other varieties of Laurentian French ${ }^{5}$ (Stelling, 2008). In comparison, European varieties of spoken French have been underrepresented (Wales, 1983; Jeanjean, 1988; Hansen and Strudsolm, 2006; Fleury and Branca-Rosoff, 2010; Lindschouw, 2011; Edmonds, Gudmestad and Donaldson, 2017; Abouda and Skrovec, 2015; Villeneuve and Comeau, 2016; Gudmestad, Edmonds, Donaldson and Carmichael, 2018).

Early studies on FTR in French focused on the distribution of the two morphological futures: the Synthetic Future (e.g. l saura) and the Analytic Future (e.g. il va savoir) without consideration for the Present that is routinely used for the same function in future contexts. The exclusion of the Present has been justified by different reasons or subsets of reasons: 1) representing less than $10 \%$ of future markings, it was considered too rare to be included in quantitative analysis (Deshaies and Laforge, 1981; Emirkanian and D. Sankoff, 1985; Blondeau, 2006; Poplack and Dion, 2009; Grimm, 2010; Comeau, 2011; Grimm and Nadasdi, 2011; Roberts, 2012); 2) present coding co-occurred with temporal expression, such as adverbs (King and Nadasdi, 2003; Blondeau, 2006; Wagner and G. Sankoff, 2011); and 3) the stability of the Present over time contrasted with the change affecting the rise of the Analytic Future at the

\footnotetext{
${ }^{5}$ Laurentian French refers to varieties of Canadian French which developed alongside the Saint-Lawrence river.
} 
expense of the Synthetic Future (Poplack and Dion, 2009; Wagner and G. Sankoff, 2011).

So far, only a few studies have considered all three variants (Poplack and Turpin, 1999; Poplack and Dion, 2009; Grimm, 2015; Blondeau and Labeau, 2016; Edmonds et al., 2017; Gudmestad et al., 2018). The exclusion of the Present from the analysis is partly due to the fact that most of the variationist studies have been based on data from semi-directed sociolinguistics interviews, where the Present variant is rare. Only recently have other types of corpora been studied: natural conversations (King and Nadasdi, 2003; Hansen and Strudsholm, 2006; Comeau, 2015; Edmonds et al., 2017, Gudmestad et al., 2018), weather reports (Blondeau and Labeau, 2016), and text messages (Labeau, 2014). These studies reported a larger presence of the Present variant, which warrants its integration in the analysis.

\subsection{Previous findings}

\subsubsection{Frequency of the variants}

In previous studies focusing on sociolinguistic interviews, the rate of Present reported is generally below the $10 \%$ threshold. Poplack and Turpin (1999) observed a rate of $7 \%$, in comparison with the two morphological futures, which were at $20 \%$ for the Synthetic Future and $73 \%$ for the Analytic Future respectively. However, recent studies report a higher frequency of 
Present, 32\% in informal conversations collected in France (Edmonds et al., 2017; Gudmestad et al., 2018), and 27.5\% in France, and $42 \%$ in Québec in prepared oral speech data (Blondeau and Labeau, 2016).

When the Present is excluded, the Analytic Future rate is largely superior to the Synthetic Future rate in most varieties of spoken French analyzed. However, the frequency differs across varieties and studies. In work on Hexagonal French, the use of Analytic Future amounts to $42 \%$ in Jeanjean (1988), 59\% in Roberts (2012), 62\% in Villeneuve and Comeau (2016), 66\% in Edmonds et al. (2017) and 66\% in Abouda and Skrovec (2015). In Laurentian French, the rates are even higher and vary from $78 \%$ (Poplack and Turpin, 1999) to $90 \%$ in Grimm (2010). In Acadian French, the Analytic Future is less common, ranging from $62 \%$ in Baie Sainte-Marie (Comeau, 2015) to $41 \%$ in St. Louis, Prince Edward Island (King and Nadasdi, 2003).

These differences in terms of rate of use among varieties are difficult to interpret since such differences might be due to many issues, such as the definition of the variable context, the data collection procedures and the position of the variable in the language change process. This is why we turn to the factors at plays, which can can provide interesting insights on the FTR variability. While social factors have been discussed in the literature, there is no clear consensus on their role. Even the age factor, which was considered as an 
indication of a change in progress in earlier studies has been reevaluated in the light of lifespan change (see Wagner and Sankoff, 2011). The linguistic factors might therefore be indicative of the structure of the variable.

\subsubsection{Linguistic Factors}

A number of linguistic factors have been analyzed in the FTR literature. Here, we focus on those that have proven to be significant in a reasonable number of studies, namely Polarity, Temporal Distance, Adverbial Specification and Contingency. Other potential factors have also been explored in previous studies, such as Subject Number and Grammatical Person (Söll, 1983; Poplack and Turpin, 1999; King and Nadasdi, 2003; Poplack and Dion, 2009; Grimm and Nadasdi, 2011; Roberts, 2012, Lindschouw, 2013), the combination with quand (Deshaies and Laforge, 1981; Emirkanian and D. Sankoff, 1985; Chevalier, 1996; King and Nadasdi, 2003; Grimm and Nadasdi,

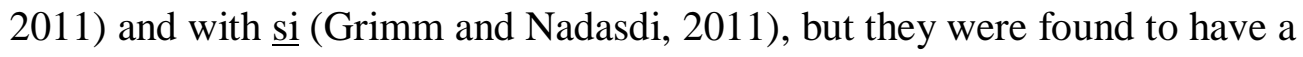
weak effect on variation. They are therefore not further explored here. We do however add another factor: Verb Type (Poplack and Turpin, 1999), as we will discuss in section 4.

The first factor, much discussed in the literature, refers to the negative or positive Polarity of the sentence. Since the work of Deshaies and Laforge 
(1981), all variationist studies focusing on Québec French have found a strong effect of the Polarity constraint, with negative contexts favoring the Synthetic Future (Emirkanian and D. Sankoff, 1985; Zimmer, 1994; Poplack and Turpin, 1999; Blondeau, 2006; Poplack and Dion, 2009; Wagner and G. Sankoff, 2011). A similar effect has been identified in other varieties of Laurentian French, although not to the same extent (Grimm, 2010, 2015; Grimm and Nadasdi, 2011). In Hexagonal French, Roberts (2012) identifies the Polarity effect as the most influential factor, though again not to the same extent as in Québec French. In most varieties of Acadian French, this constraint is not operative (King and Nadasdi, 2003; Comeau, 2015), a phenomenon that has been interpreted as a reflection of the conservative nature of these varieties ${ }^{6}$.

The Temporal Distance factor refers to the period of time between the moment of speech and the future event ${ }^{7}$. While Temporal Distance has been the main criterion cited by prescriptivists to distinguish between the Synthetic and Analytic Futures, this factor is not at play in all varieties studied. Temporal Distance is not operative or shows a weak effect in Laurentian French (Poplack

${ }^{6}$ In their overview of the treatment of FTR in 163 grammars over five centuries (1500-1999), Poplack and Dion (2009) found that the effect of polarity was mentioned only in one recent manual dated 1995, 'at least a century after the association [between the SF and negative polarity] had become virtually categorical in speech' (p.575).

7 A series of contextual factors can be involved in the interpretation of the temporal distance (Lindschouw 2011). 
and Turpin, 1999; Blondeau, 2006; Grimm and Nadasdi, 2011), but it is significant in Acadian French (King and Nadasdi, 2003; Comeau, 2015), in Vimeu French (Villeneuve and Comeau, 2016), and Martinique French (Roberts, 2014, 2016), where distal events favour the Synthetic Future and proximal events tend to be expressed with the Analytic Future, a result in line with the prescriptive claims offered by grammarians.

Adverbial Specification has been observed in most of the previous studies but with no clear agreement on its role. Non-specific adverbs favor the Synthetic Future, the absence of Adverbial Specification is associated with the Analytic Future, and specific adverbs favour the Present variant (Poplack and Turpin, 1999). However, there are conflicting results and no real consensus since the adverbial constraint plays a role in some studies on Laurentian and Acadian French (Poplack and Dion, 2009; Comeau, 2015) but not in others (excluding the Present) (King and Nadasdi, 2003 ${ }^{8}$; Blondeau, 2006). Two more recent studies based on a corpus of informal conversation in France integrates

${ }^{8}$ Grimm and Nadasdi (2011) report that Adverbial Specification plays no role in conditioning variation in the 1978 Ontario French corpus (Mougeon and Beniak, 1991). However, Grimm (2010) reports that this factor does condition variant choice in Hawkesbury (one of the Ontario French communities in the 2005 Ontario French corpus) where the Analytic Future is favoured in the presence of specific and non-specific adverbial specification. 
adverbs with other discursive cues in the referential context that encourage the use of the Present (Edmonds et al., 2017; Gudmestad et al., 2018).

Finally, Contingency, first proposed in Deshaies and Laforge (1981), has proven significant in Québec French (Poplack and Turpin, 1999; Blondeau, 2006; Wagner and G. Sankoff, 2011), where the Synthetic Future was associated with uncertainty in a future eventuality and the Analytic Future with certainty. The way to define and operationalize the Contingency factors has been extensively discussed in Wagner and Sankoff (2011). In Acadian French, this factor group was also selected as significant (King and Nadasdi, 2003), although a more recent study (Comeau, 2015) showed that this is not the case in some Acadian communities.

In sum, varieties distinguish themselves in relation to two main linguistic factors: Polarity and Temporal Distance. The Synthetic Future has proven frequent in negative contexts in Québec French (Emirkanian and D. Sankoff, 1985; Poplack and Turpin, 1999; Wagner and G. Sankoff, 2011, among others), while other studies have shown evidence of a Temporal Distance effect in Hexagonal and Acadian French (King and Nadasdi, 2003; Roberts, 2012). There is no consensus about the role of the Present variant, which has been under-investigated. 


\section{The challenge of circumscribing the variable context of FTR}

The first step of any variationist study is generally devoted to the delimitation of the envelope of variation. An explicit definition of the linguistic variable under scrutiny, as well as a statement about the principled decision regarding the delimitation of what counts and does not count are considered essential to ensure replicability. On the one hand, one can advocate for a stricter delimitation of the envelope of variation to only include cases of alternation that are in a close relationship, such as Blake's (1997) analysis of copula in African American English . On the other hand, one can advocate for a more extensive or inclusive definition of the envelope, such as Aaron's (2010) study of the grammaticalization process involved in FTR variation in Spanish. The decision of what tokens to include or not to include constitutes a crucial issue closely related to the research questions. In this paper, following previous work on FTR in French (Edmonds et al., 2017 and Poplack \& Dion, 2009) and Spanish (Kanwit, 2017), we advocate for a function-based approach to variation. As we saw in the previous sections, three variants can be used to express Future Temporal Reference in French: the Analytic Future, the Synthetic Future and the Present. The Principle of Accountability requires the inclusion of all three variants in the analysis (Gudmestad et al., 2018). The 
inclusion of Futurate Present in the envelope of variation raises further questions related to the relationship between variants, which we discuss in section 6.2.

As recently pointed out by Labov, the issue of covariation of form and meaning remains a challenge 'in the background -and often foreground' of variationist studies (2017: 519). The linguistic variable has initially been argued to be subject to a Synonymy Principle (Labov, 1972:118). While this synonymy, or referential equivalence, is unproblematic for phonological and some morphosyntactic variables, such as the variable presence of the suffix $-\mathrm{s}$ in third person singular contexts in English, the extension of sociolinguistic inquiry 'above and beyond' phonology (G. Sankoff, 1973) led to a debate about which variants meet this criterion (Labov, 1978; Lavandera, 1978). Do the forms that vary need to be two ways of saying the same thing (strict synonymy), or do they merely have to have the 'same function in discourse' (Dines, 1980)? Form-based approaches consider only variants that alternate with each other in a single (non-complementary) context or variants that are used for an identical meaning. In contrast, a function-based approach considers a linguistic function and includes in the envelope of variation all variants that convey that function. Such an approach 'side-steps the requirement of strict 
semantic equivalence of variants' (Walker, 2013: 443) to the advantage of a 'weak equivalence' (D. Sankoff and Thibault, 1981).

In their review of FTR in the French language over more than two centuries, Poplack and Dion (2009) demonstrated that the quest to establish a strict equivalence has led linguists and grammarians to identify semantic differences that were not supported by empirical data and were often contradictory. These considerations led us to adopt a function-based approach which provides a weak equivalence answer to the Synonymy problem - and thus to include in the envelope of variation all forms, and only forms, that convey the FTR function. In accordance with Labov's Principle of Accountability (Labov, 1972:72), this means that the envelope of variation also encompasses all instances where the variants could have occurred but did not. This is generally meant to allow the researcher to then quantify usage percentage for each variant, including zero variants. In the case of FTR, this means that the set of variants contains not only forms morphologically marked for future tense, be they Analytic or Synthetic, but also the non-morphogicallyovert variant - the Futurate Present. The Futurate Present, being nonmorphologically-marked for Future tense, instantiates the zero variant of the Tense morpheme. 
As we saw in section 2.2.1, low rates of Futurate Present in semidirected interviews often prevented previous studies on FTR from considering this variant in the envelope of variation. Fortunately, corpora of text messages do not face the same challenge. On the contrary, because of their conversational nature $^{9}$, we observe very high rates of the Futurate Present in this context. Text messages thus provide a unique opportunity to explore the linguistic and extralinguistic conditioning of the Futurate Present in a naturalistic environment, and the relation of this variant with the other two.

\section{Methods}

\subsection{Corpora}

For the present study, we used two corpora of text messages from Québec and Belgium from the international SMS4science project (http://www.sms4science.org) coordinated by the CENTAL in Belgium. The two corpora were collected on a voluntary basis ${ }^{10}$ via a campaign 'Faites don de

9 Tremblay (submitted) has argued that text messages are often parts of very informal conversations between intimates. See section 6.2 for discussion.

${ }^{10}$ For both corpora, the data collection was done on a voluntary base, and the participants forwarded the text messages to the project team after they were sent to the intended recipient. Meta-data information was collected for each donor but, the reader has to keep in mind that the body of data collected does not represent the entire community and does not correspond to a stratified sample (for more details on the data collection, see Fairon et al., 2006 and Langlais et al. 2012). 
vos textos à la science', which encouraged the public to send text messages they had written to the project. Because of the way the data was collected, the two corpora only contain individual text messages, and not the whole conversations they were part of.

The corpus from Belgium, SMS4science (Fairon et al., 2006), contains 30,000 text messages written by 2,436 authors, aged between 12 and 65 years. Some groups are over-represented: $57.2 \%$ of the corpus was provided by female informants; over $60 \%$ of informants fell in the $15-24$ age range; and most were university-educated (Cougnon and François, 2010). The Québec corpus Texto4science (Langlais et al., 2012; Langlais and Drouin, 2012) comprises 6,870 text messages collected in 2009-2010. Of the 298 participants, $54 \%$ were between 20 and 29 years old, $63 \%$ were female and $60 \%$ were university-educated. The two corpora thus show similar bias towards younger, educated female participants. This similarity in sampling ensured the comparability of the two corpora.

Each text message was also normalized as illustrated in example (3) from the Belgian corpus:

Original text Vwala c fè mnt v me conecT sur msn pr kil se deco é i sora+se reco.VENGEANCE.jtexplikrè $2 \mathrm{~m} 1$

(3') Normalized version 
Voilà c'est fait maintenant vais me connecter sur MSN pour qu'il se déconnecte et il saura plus se reconnecter. VENGEANCE. Je t'expliquerai demain 'Well it's done now, ' am going to connect to MSN so he is going to disconnect and he won't be able to reconnect. REVENGE. I'll explain tomorrow.'

(BG, user 69)

\subsection{Extraction and exclusions}

We first extracted a total of 3,092 tokens (1,564 from the entire Québec corpus and a similar number of 1,528 text messages from Belgium) and then excluded fixed expressions such as on verra 'we'll see', and the forms not pertaining to Future Temporal Reference such as verbs of movement (4a), or ambiguous cases of verbs of movement (4b), and habituals ${ }^{11}(4 c)$. After the exclusion process, we retained a total of 2,600 tokens: 1,326 from the Québec corpus and 1,274 from the Belgium corpus.

(4) a. Pcq jtaek Alain au tim on va tu tchercher? Parce que je suis avec Alain au Tim. On va-tu te chercher? 'Because I'm with Alain at Tim Horton's are we going to pick you up?'

[QC: user_ 112339]),)

b. Jvais souper chez des amis! Je vais souper chez des amis!

'I'm going to eat at my friends' place'

[QC: user_111817])

c. ds n importe quelle urgence, tu seras tjs examinée par un étudiant dans n'importe quelle urgence, tu seras toujours examinée par un étudiant

'in any ER, you will always be examined by a student' [BC: user183])

${ }^{11}$ Habituals have been excluded from many variationist analyses and Leblanc $(2007,2009)$ has shown that this variable context is not constrained in the same way as Future Temporal Reference. 


\subsection{Coding the factors}

For the analysis we coded for a total of 7 factor groups. The two extralinguistic $^{12}$ factor groups were Community (Belgium or Québec) and Gender (female, male or undeclared). In total, we coded data from 233 participants, 125 participants from the Québec corpus (64 Females, 23 Males and 38 undeclared gender), and 108 participants from the Belgium corpus (62 Females, 45 Males and 1 undeclared gender).

The five linguistic factor groups were: Temporal Distance, Adverbial Specification, Contingency, Polarity, and Verb Type. As we saw in section 2.2.2, the first four factors have proven significant in a number of previous studies. To better understand the possible role of the morphological class of the verb, we included a fifth factor, Verb Type.

An important factor group discussed in all previous studies is the effect of Temporal Distance ${ }^{13}$. Therefore, we coded to specify the distance of the future event from the moment of speaking. For comparative purposes, we opted for a quadripartite categorization, distinguishing future events occurring within

\footnotetext{
${ }^{12}$ As mentioned above, the corpora were not socially-stratified, and some groups were under-represented (older and less-educated participants). Consequently, our analysis does not include Age and Education amongst the extralinguistic factors. ${ }^{13}$ Temporal distance has been abundantly discussed in the literature. Our choice of coding scheme is in line with previous studies in variationist sociolinguistics. However we are aware that numerous contextual clues are involved in the interpretation of Future Temporal Reference as well as in the measurement of the temporal distance.
} 
24 hours (today) (5a), within the next day (tomorrow) (5b), greater than a day (after tomorrow) (5c), and unspecified (5d).

(5) a. Tk texte moi kan tu part de la on va aller tattendre ch vs En tout cas, texte-moi quand tu pars de là, on va t'atenndre chez vous 'Anyway, text me when you leave, we'll wait for you at your place.'

(QC, user_112339)

b. Non jva le caller demain matin

Non je vais le caller demain matin

'No I'll call him tomorrow morning'

(QC, user_112332

c. Lol my god t une brute, faut ajouter une source a Virginie, si tu travail en fin dsemaine ma tle montrer

Lol my god t'es une brute, il faut ajouter une source à Virginie, si tu travailles en fin de semaine, je vais te le montrer.

'Lol my god you are a brute. A source need to be added to Virginie, if you work this weekend, I'll show you.

(QC, user_110270)

d. Kk mais jtaverti tout de suite que moi jfais du benevolat so jvais etre pas mal occupee...

Ok ok mais je t'avertis tout de suite que moi je fais du bénévolat so je vais être pas mal occupée.

'Ok ok but I'm warning you now that I do volunteer work so I'll be pretty busy.'

(QC, user_110250)

For the Polarity effect we adopted the binary coding used by most

previous studies opposing positive and negative. As mentioned in section 2.2.2,

polarity has been shown to be a strong predictor in Québec French, but not in

Acadian French. We wanted to test if Polarity was also a factor distinguishing

the Québec and Belgium French corpora.

The first study of FTR suggested that the certainty of future

eventualities was influential in the variation; Analytic Future being associated 
with more certainty than Synthetic Future (Deshaies and Laforge, 1981). This notion of Contingency was also tested by Poplack and Turpin (1999) who distinguished contingent and assumed future events. To operationalize the Contingency effect, and in order to establish a comparison with a previous study on spoken data (Blondeau, 2006), we opposed non-contingent future eventualities with contingent ones, and, among the latter, distinguished two sub-categories of contingent events introduced by if (6a) or by when (6b) (Blondeau, 2006).

(6) a. Salut grand frère cmt va?Just un peti cl1 d'oeil pr t dir q si ce soir il te pren une envi d découvrir d nveau endroi pr danser..j'y GOUTERAI volontier av toi

Salut grand frère comment ça va ? Juste un petit clin d'œil pour te dire que si ce soir il te prend une envie de découvrir de nouveaux endroits pour danser.. j'y gouterai volontiers avec toi.

'Hello big brother how are you ? Just a little wink to tell you that if you feel like discovering new dance places tonight, I'd be happy to taste it with you'

(BG, user 15)

b. Ouai en bref on fera jms ke sengueulé kan on se parlera! Mai jsai pa si c la meilleur dé ch!

Ouais en bref on fera jamais que s'engueuler quand on se parlera! Mais je sais pas si c'est la meilleure des choses.

'Yeah in short we'll only fight when we talk to each other. But I don't know if that's the best thing.'

(BG, user 19)

To see if and how Adverbial Specification was constraining the variation, we followed previous studies and coded for absence vs. presence of 
FTR adverbs, further distinguishing between specific adverbs (demain 'tomorrow', à 9h 'at 9') and non-specific ones (ientôt 'soon', plus tard 'later').

Finally, given that the variable at hand involves morphological variants, we investigated the effect of the morphological class of the verb on the choice between variants. We coded for the type of verb, an aspect often neglected in other studies of FTR in spoken French (with the exception of Poplack and Turpin, 1999). Since the degree of regularity of the verb had an effect on the variation in prepared speech in Québec and in France (Blondeau and Labeau, 2016), we wanted to further explore this hypothesis by refining the categories.

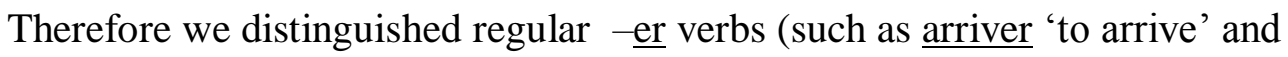

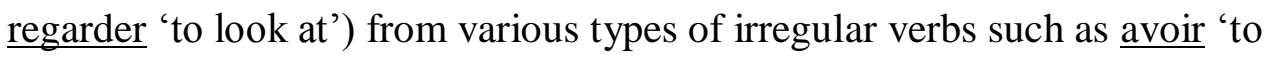
have', être 'to be', modal verbs (such as pouvoir 'can', devoir 'must'), and remaining irregular verbs (such as partir 'to leave', boire 'to drink'). This allowed us to explore the role of various semantic or morphological distinctions among irregular verbs.

\subsection{Statistical analyses}

We used the variable rule program GoldVarb Lion (Rand and D.Sankoff, 1990; D. Sankoff, Tagliamonte and Smith, 2005) to conduct the multivariate analysis. We first measured the effect of Community by running all the data 
together. Once the effect of Community was shown to be significant, in line with comparative sociolinguistics (Poplack and Tagliamonte, 2001;

Tagliamonte, 2002), we ran distinct multivariate analyses for each community, recording similarity in the patterning of variability — similarity in significance, range and ranking — as an indication of similar underlying grammars.

Conversely, dissimilarities in significance, range and ranking were interpreted as an indication of different underlying grammars.

\section{Results}

\subsection{General tendencies}

The overall distribution of the three major variants of FTR is given in Table 1. This table shows that the Present is the preferred means of expressing FTR in both communities, accounting for close to half of the data ${ }^{14}$. Moreover, while in Belgium, the Synthetic Future closely follows the Futurate Present, in Québec, the Analytic Future comes second. While these results corroborate empirical reports of Canadian French, the much higher rate of Synthetic Future

\footnotetext{
${ }^{14}$ It is very likely that our study underestimates the rate of Futurate Present. As mentioned in section 4.1, we did not have access to the entire conversations. Consequently, we had to rely on readily available (explicit) contextual cues, such as adverbs, to identify the Futurate Present. Crucially, the extraction procedure was the same in the two corpora.
} 
in the Belgian corpus is a relatively new finding ${ }^{15}$, which will need corroboration to see how this dialect is different from other varieties of European French. Indeed, these results have yet to be compared with other results from Belgium.

\begin{tabular}{|l|l|l|l|l|}
\hline & \multicolumn{2}{|c|}{ Belgium } & \multicolumn{2}{c|}{ Québec } \\
\hline & $\%$ & $\mathrm{~N}$ & $\%$ & $\mathrm{~N}$ \\
\hline Analytic Future & 15.3 & 195 & 32.1 & 425 \\
\hline Present & 46.2 & 588 & 48.9 & 648 \\
\hline Synthetic Future & 38.5 & 491 & 19.1 & 253 \\
\hline TOTAL & & 1,274 & & 1,326 \\
\hline
\end{tabular}

Table 1: Distribution of FTR variants in Belgium and Québec corpora of text messages

In the spirit of Poplack and Turpin (1999), we first opposed each variant with the two other competing variants ${ }^{16}$. Table 2 displays the results of the variable analyses with respect to the two extralinguistic factor groups. While Gender is never significant, we observe a Community effect only for the Synthetic and the Analytic Future, but not for the Present, which is used at rates well above $40 \%$ in both Belgium and Québec.

${ }^{15}$ Our results for the Belgian corpus confirm those found in Labeau (2014), who examined the use of Analytic (26/74) vs. Synthetic (48/74) Future in text messages from the same sub-corpus.

${ }^{16}$ A different approach is taken in Gudmestad et al. (2018), which advocates for the consideration of all three FTR variants (the inflectional future, periphrastic future, and present indicative) as separate forms within a single statistical model. 


\begin{tabular}{|c|c|c|c|c|c|c|c|c|c|}
\hline & \multicolumn{3}{|c|}{$\begin{array}{l}\text { Present vs. } \\
\text { Analytic/Synthetic }\end{array}$} & \multicolumn{3}{|c|}{$\begin{array}{l}\text { Synthetic vs. } \\
\text { Present/Analytic }\end{array}$} & \multicolumn{3}{|c|}{$\begin{array}{l}\text { Analytic vs. } \\
\text { Present/Synthetic }\end{array}$} \\
\hline & \multicolumn{3}{|c|}{$\begin{array}{l}\text { Input: } .475 \\
\text { Loglikelihood: } \\
\mathrm{N}=2600\end{array}$} & \multicolumn{3}{|c|}{$\begin{array}{l}\text { Input: } .276 \\
\text { Loglikelihood: } \\
\mathrm{N}=2600\end{array}$} & \multicolumn{3}{|c|}{$\begin{array}{l}\text { Input: .228 } \\
\text { Loglikelihood: } \\
\mathrm{N}=2600\end{array}$} \\
\hline Community & FW & $\%$ & $\mathrm{~N}$ & FW & $\%$ & $\mathrm{~N}$ & FW & $\%$ & $\mathrm{~N}$ \\
\hline Belgium & $\mathrm{NS}$ & $46.2 \%$ & 1,274 & .622 & 38.5 & 1,274 & .380 & 15.3 & 1,274 \\
\hline Québec & $\mathrm{NS}$ & $48.9 \%$ & 1,326 & .383 & 19.1 & 1,326 & .615 & 32.1 & 1,326 \\
\hline range & & & & & & 24 & & & 23 \\
\hline \multicolumn{10}{|l|}{ Gender } \\
\hline Female & NS & $46.8 \%$ & 1,555 & NS & 26.8 & 1,555 & NS & 26.5 & 1,555 \\
\hline Male & $\mathrm{NS}$ & $48.8 \%$ & 693 & NS & 33.9 & 693 & NS & 17.3 & 693 \\
\hline Undeclared & $\mathrm{NS}$ & $48.6 \%$ & 352 & NS & 26.4 & 352 & $\mathrm{NS}$ & 25.0 & 352 \\
\hline
\end{tabular}

Table 2: Effect of Community and Gender on choice of the three FTR variants.

However, the inclusion of the Present in the analyses of Table 2

weakens the community effect observed in the choice of the Synthetic or Analytic Future. The community effect is even stronger when the Present is excluded, as shown in Table 3.

\begin{tabular}{|c|c|c|c|}
\hline & \multicolumn{3}{|c|}{ Synthetic vs. Analytic } \\
\hline & \multicolumn{3}{|c|}{$\begin{array}{l}\text { Input: } .551 \\
\text { Loglikelihood: } \\
\mathrm{N}=1364\end{array}$} \\
\hline Community & FW & $\%$ & $\mathrm{~N}$ \\
\hline Belgium & .672 & 71.6 & 686 \\
\hline Québec & .327 & 37.3 & 678 \\
\hline range & & & \\
\hline \multicolumn{4}{|l|}{ Gender } \\
\hline Female & NS & 50.2 & 828 \\
\hline Male & NS & 66.2 & 355 \\
\hline Undeclared & NS & 51.4 & 181 \\
\hline
\end{tabular}

Table 3: Effect of Community and Gender on choice of the Synthetic vs. Analytic Future 
To summarize, the choice of the Present versus the other two variants does not appear to be conditioned by the community ${ }^{17}$, and dialectal variation lies strictly in the choice of the Analytic versus the Synthetic Future. The next two sections confirm this claim by looking at the linguistic factors constraining the use of the three variants in each community.

\subsection{Present vs. morphological future}

We first compare the effect of the linguistic factors in the choice of the Present over the two morphological futures in the two communities. Table 4 shows that not only are the rates of the Present similar, but also that the underlying grammar governing the choice of the variant is strikingly similar. First, the same two factor groups were rejected by the analysis as non-significant: Polarity and Temporal Distance. These results confirm the findings of Poplack and Turpin (1999), who also found that the choice of the Present variant was not subject to these two factor groups. Second, as shown in previous studies (Poplack and Turpin, 1999; Edmonds et al., 2017), the absence of Adverbial Specification, whether specific or non-specific, disfavors the use of the Present. Furthermore, with respect to Contingency, our results show that the Present is favoured in the context of a clause introduced by quand, but

\footnotetext{
${ }^{17}$ While our study shows that the frequencies in the use of the Present is the same in the two communities, it does not preclude the possibility that the two communities use the Present in different contexts.
} 
disfavored in the context a clause introduced by $\underline{s i}$. Finally, not only has Verb Type proven to be significant, but we observe the same pattern with modal and irregular verbs favouring the Present, and regular and être disfavouring it. The hierarchy of factors in this group seems to indicate that the choice of Present is sensitive to the semantic, rather than morphological, class of the predicate. 


\begin{tabular}{|c|c|c|c|c|c|c|}
\hline \multirow{2}{*}{$\begin{array}{l} \\
\text { FACTOR } \\
\text { ADVERB } \\
\end{array}$} & \multicolumn{3}{|c|}{$\begin{array}{l}\text { Québec } \\
\text { Input }=.482 \\
\text { Total } n=1326\end{array}$} & \multicolumn{3}{|c|}{$\begin{array}{l}\text { Belgium } \\
\text { Input }=.445 \\
\text { Total } n=1274\end{array}$} \\
\hline & $\begin{array}{l}\text { FACTOR } \\
\text { WEIGHT } \\
\end{array}$ & $\%$ & $\mathbf{N}$ & $\begin{array}{l}\text { FACTOR } \\
\text { WEIGHT }\end{array}$ & $\%$ & $\mathbf{N}$ \\
\hline specific & .678 & 64.6 & 618 & .634 & 61.8 & 671 \\
\hline non specific & .636 & 62.8 & 148 & .561 & 45.6 & 125 \\
\hline absence & .275 & 28 & 560 & .302 & 24.3 & 478 \\
\hline range & 40 & & & 33 & & \\
\hline \multicolumn{7}{|l|}{ Verb Type } \\
\hline modal & .689 & 66.1 & 115 & .555 & 50.3 & 175 \\
\hline irregular & .571 & 54.3 & 521 & .626 & 58.6 & 483 \\
\hline $\begin{array}{l}\text { Avoir } \\
\text { « have » }\end{array}$ & .511 & 51.6 & 64 & .486 & 42.6 & 54 \\
\hline regular & .473 & 46 & 435 & .462 & 40.1 & 357 \\
\hline$\hat{E} t r e$ "be » & .262 & 29.3 & 191 & .246 & 24.9 & 205 \\
\hline range & 43 & & & 38 & & \\
\hline \multicolumn{7}{|l|}{ Contingency } \\
\hline $\begin{array}{l}\text { Quand } \\
\text { «when » }\end{array}$ & .746 & 60 & 20 & .874 & 69.6 & 23 \\
\hline $\begin{array}{l}\text { non } \\
\text { contingent }\end{array}$ & .502 & 49.3 & 1262 & .587 & 45.7 & 1198 \\
\hline $\mathrm{Si} \ll$ if $»$ & .330 & 31.8 & 44 & .411 & 45.3 & 53 \\
\hline range & 41 & & & 46 & & \\
\hline \multicolumn{7}{|l|}{ POLARITY } \\
\hline negative & NS & 42,7 & 82 & $\mathrm{NS}$ & 36,9 & 130 \\
\hline positive & NS & 49,3 & 1244 & $\mathrm{NS}$ & 47,2 & 1144 \\
\hline \multicolumn{7}{|l|}{$\begin{array}{l}\text { TEMPORAL } \\
\text { DISTANCE }\end{array}$} \\
\hline $\begin{array}{l}\text { After } \\
\text { tomorrow }\end{array}$ & NS & 61,7 & 141 & $\mathrm{NS}$ & 59,7 & 186 \\
\hline tomorrow & NS & 62,8 & 137 & $\mathrm{NS}$ & 65,8 & 196 \\
\hline unspecified & NS & 38,2 & 636 & $\mathrm{NS}$ & 27,8 & 558 \\
\hline today & NS & 56,3 & 412 & NS & 57,8 & 334 \\
\hline
\end{tabular}

Table 4: Effect of the linguistic factors on choice of the Present variant in Québec and Belgium 
To summarize, the use of the Present over the morphological future is not sensitive to dialectal variation. Both communities use the Present to the same extent, and share the constraints governing its use. The next section shows that the situation is quite different when morphological futures are contrasted.

\subsection{Synthetic vs. Analytic Future}

We now compare the effect of the linguistic factors on the choice of the Synthetic Future over the Analytic Future in the two communities. For the current analysis, the application value is the Synthetic future. As shown in

Table 5, the two communities are similar with respect to Contingency, which was not selected as significant, and Temporal Distance, which is significant and patterns similarly in both communities, with greater Temporal Distance favoring the Synthetic Future. These results contrast with previous studies on Canadian French. We have seen in section 2.2.2 that numerous studies based on semi-directed interviews have shown that this factor group is not significant in Laurentian French. Our results for the Québec corpus are the only one to attribute a role to the temporal distance for this variety. We will return to this question in the discussion. With respect to Contingency, the Synthetic Future has been associated with certainty in previous research on Canadian French (Poplack and Turpin, 1999; King and Nadasdi, 2003). 
The two communities diverge however with respect to Polarity and Adverbial Specification. In Québec, the use of the Synthetic Future is strongly favoured in negative environments, as indicated by the range of 44, a result in keeping with previous research on Laurentian French. The situation is different in Belgium, where this factor group was not selected as significant, as in Acadian French. Conversely, Adverbial Specification is not significant in Québec, but is significant in Belgium, where the presence of (specific) adverbs favors the use of the Synthetic Future.

The two communities also differ with respect to Verb Type. The same Verb Types favour the Synthetic Future: to be, to have, and modals. Other verbs disfavor the use of the Synthetic Future. The two communities contrast however in that the range is 27 in Québec, and 49 in Belgium, which indicates that this factor group has a stronger effect in the latter community. Table 5 thus shows that morphological complexity is at stake in both communities: the more irregular the paradigm, the more likely the use of the Synthetic Future. Presumably, such irregular forms need to be learned and stored in the mental lexicon, which in turn facilitates lexical access. The use of the Synthetic form in such cases may indicate that such stored forms are more accessible than words that need to be formed online. This may also be linked to a frequency effect. 


\begin{tabular}{|c|c|c|c|c|c|c|}
\hline \multirow[b]{2}{*}{ FACTOR } & \multicolumn{3}{|c|}{$\begin{array}{r}\text { Québec } \\
\text { input }=.370 \\
\text { Total } n=678\end{array}$} & \multicolumn{3}{|c|}{$\begin{array}{r}\text { Belgium } \\
\text { Input }=.750 \\
\text { Total } n=686\end{array}$} \\
\hline & $\begin{array}{l}\text { FACTOR } \\
\text { WEIGHT }\end{array}$ & $\%$ & $\mathbf{N}$ & $\begin{array}{l}\text { FACTOR } \\
\text { WEIGHT }\end{array}$ & $\%$ & $\mathbf{N}$ \\
\hline \multicolumn{7}{|l|}{ POLARITY } \\
\hline negative & .899 & 85.1 & 47 & NS & 81.7 & 82 \\
\hline positive & .459 & 33.8 & 631 & NS & 70.2 & 604 \\
\hline range & 44 & & & & & \\
\hline \multicolumn{7}{|l|}{ ADVERB } \\
\hline specific & $\mathrm{NS}$ & 42.9 & 219 & .636 & 78.9 & 256 \\
\hline non specific & NS & 38.2 & 55 & .555 & 77.9 & 68 \\
\hline absence & NS & 34.2 & 404 & .393 & 65.2 & 362 \\
\hline range & & & & 24 & & \\
\hline \multicolumn{7}{|l|}{ VERB TYPE } \\
\hline être & .670 & 54.1 & 135 & .711 & 88.3 & 154 \\
\hline avoir & .623 & 54.8 & 31 & .843 & 93.5 & 31 \\
\hline modal & .597 & 51.3 & 39 & .625 & 81.6 & 87 \\
\hline irregular & .463 & 32.4 & 238 & .368 & 63.0 & 200 \\
\hline regular & .404 & 28.1 & 235 & .356 & 60.3 & 214 \\
\hline range & 27 & & & 49 & & \\
\hline \multicolumn{7}{|l|}{ DISTANCE } \\
\hline After tomorrow & .679 & 55.6 & 54 & .568 & 81.3 & 75 \\
\hline tomorrow & .528 & 37.3 & 51 & .615 & 80.6 & 67 \\
\hline unspecified & .492 & 36.4 & 393 & .517 & 72.2 & 403 \\
\hline today & .453 & 33.9 & 180 & .362 & 60.3 & 141 \\
\hline range & 23 & & & 25 & & \\
\hline \multicolumn{7}{|l|}{ CONTINGENCY } \\
\hline Quand « when » & NS & 62.5 & 8 & $\mathrm{NS}$ & 85.7 & 7 \\
\hline $\mathrm{Si} \ll$ if $»$ & NS & 43.3 & 30 & NS & 82.8 & 29 \\
\hline non contingent & $\mathrm{NS}$ & 36.7 & 640 & $\mathrm{NS}$ & 70.9 & 650 \\
\hline & & & & & & \\
\hline
\end{tabular}

Table 5: Logical regression analyses of internal factors contributing to the probability of the Synthetic Future over the Analytic Future to express FTR in Québec and Belgium 
To summarize, Table 5 shows that the choice of the Synthetic Future over the Analytic Future is subject to dialectal variation. The underlying grammars governing the choice of the Synthetic Future over the Analytic Future share some features, such as the lack of significance of Contingency and similar trends in the distribution of verb types and adverbials categories, but clearly differ in the significance of the presence of an adverbial and especially in the role played by negative Polarity, which confirms the affinity of Synthetic Future with negation characteristic of Laurentian varieties.

\section{Discussion}

\subsection{The relationship between FTR variants}

The inclusion of the Futurate Present in the envelope of variation poses a conceptual challenge: since this variant is not overtly marked for future tense, it is not clear whether this variant should be considered on a par with the other two variants, or rather singled out as qualitatively different. The results of our comparative study of text messages in Belgian and Québec French allows us to explore this issue.

On the one hand, one can treat the Futurate Present, the Analytical Future and the Synthetic Future as three morphological variants of FTR. Under 
this view there would be only one, non-hierarchical variable context as illustrated in Figure 1.

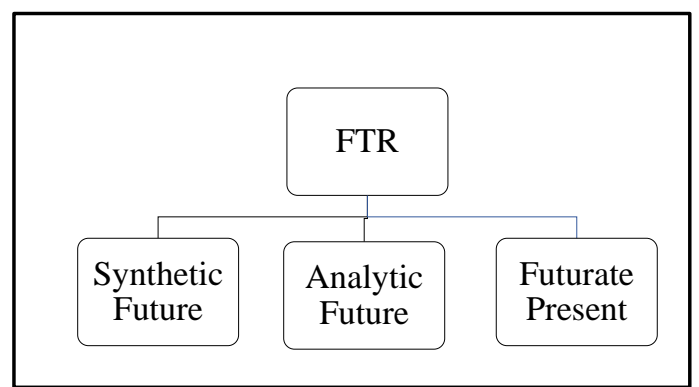

Figure 1: Non-hierarchical structure

Another possibility would be to oppose the Present and the two morphological futures. Under this view, only the Synthetic and Analytic Futures are morphological variants of FTR. In contrast, the Present, which is not morphogically-marked for future tense, is a covert variant of FTR. This identifies two distinct variable contexts which we represent with the hierarchical structure displayed in Figure 2. The two variable contexts are: 1Overt T (the Future) vs. Covert T (the Present); and 2- the Synthetic Future and the Analytic Future are morphological variants of Overt T.

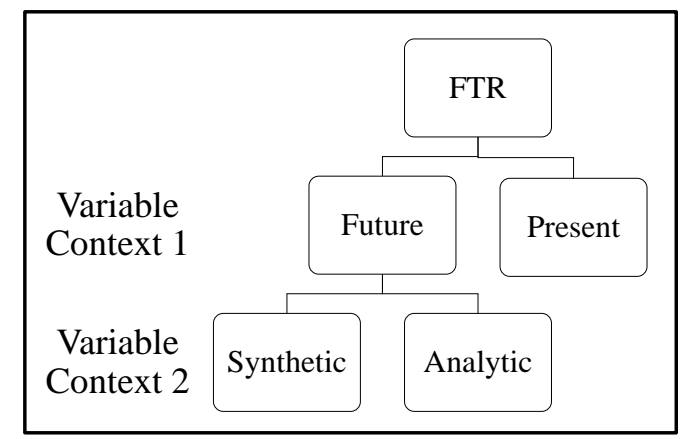


Figure 2: Hierarchical structure

The two hypotheses make different predictions with respect to dialectal variation.

Consider first the hypothesis that the three variants are morphological variants (Figure 1). Under the assumption that morphology is the locus of crosslinguistic differences (Chomsky 1995), we would expect all three variants to be sensitive to dialectal variation: different dialects would have different rates for all three variants, including the Futurate Present, and the three variants would be subject to different linguistic constraints. Moreover, since there is no principled motivation to single out any of the three morphological variants with respect to the presence or absence of contextual cues, we do not expect the choice of any of the three variants to be sensitive to the interactional context: conversations and semi-directed interviews would not display different rates of any of the three morphological variants.

The hypothesis that there are two variable contexts (Figure 2) leads to different predictions. Since Covert T is semantically under-determined, it must rely heavily on contextual cues. We thus expect the choice between Covert T (the Present) and Overt T (the Future) to be sensitive to the interactional context, as some contexts provide more such contextual cues than others. No prediction is made with respect to dialectal variation, as Covert $\mathrm{T}$ is not a 
morphological variant of Overt T. We expect the choice between the Synthetic and the Analytic Future to show the exact opposite. First, we do not expect the choice between the Synthetic and the Analytic future to be sensitive to the interactional context, as neither form is semantically under-determined and thus neither must rely of contextual cues. However, if dialects show differences in their use of the FTR variants, we expect these differences to be limited to the choice between the two morphological variants, that is the Synthetic and the Analytic Future, since only these two forms are morphologically-marked for future tense.

Our comparative analysis of text messages from Belgium and Québec supports the claim that the FTR envelope of variation is structured as in Figure 2. First, our results show that the choice of between Covert $\mathrm{T}$ and Overt $\mathrm{T}$ is sensitive to the interactional context: text messages in both communities present much higher rates of Futurate Present than has been reported in studies based on semi-directed interviews. This is expected given the conversational nature of text messages. Second, the choice between Covert T (the Present) and Overt $\mathrm{T}$ (the morphological futures) does not appear to be sensitive to dialectal variation, as both communities show similar rates and have similar grammars. Dialectal variation is limited to the choice between the two morphological variants: the Synthetic Future and the Analytic Future. Not only do the two 
communities display very different rates of these two variants, but the underlying grammars governing the choice of the Synthetic over the Analytic Future are also different in the two communities.

Finally, diachronic evidence provides further support for the twocontext hypothesis. We just saw that this hypothesis predicts that only the choice between the Analytic and Synthetic variants, but crucially not the choice between the Present and the morphological futures, will be subject to dialectal variation. With respect to change over time, the two-context hypothesis also predicts that diachronic variation should show a similar partition. This prediction is supported by Poplack and Dion (2009), who report the stability of the Present over time (119 years) in terms of both rate and conditioning in Québec French. This contrasts with the change observed in the Analytic Future, which increases at the expense of the Synthetic Future during the same period.

\subsection{The conversational nature of text messages}

Text messages constitute a valuable resource in corpus linguistics, as interactions of such proximity give us access to the vernacular. Text messages are often very informal conversations between intimates and, because they do not rely on an interviewer, they reduce the observer's paradox. People text in 
their day-to-day lives not only to plan upcoming events, but also to share feelings, maintain contact or, as in the examples below, wish good night.

a. Bonne nuit mon amour dors bien Jtm fort et Dsl mais demain on se verra po kiss (BG, user 42 )

Bonne nuit mon amour. Dors bien. Je t'aime fort et désolé mais demain on se verra pas. Kiss.

'Good night my love. Sleep well. I love you and sorry but tomorrow we won't see each other. Kiss.'

b. $\quad$ L heure du dodo a sonné pour moi! Bonne nuit! ;-)

'It's bedtime for me ! Good night! ;-) (QC, user xxx)

c. Demain matin, tu me call ${ }^{18}$ quand tu te wake up! Bonn nuit! ;-) 'Tomorrow morning, you call me when you wake up! Good night! ;-) (QC, user $\mathrm{xxx}$ )

Text messages have often been decried as deviant from the written

standard. Rather than being deviant, our study shows that text messages obey a different set of norms, closer to that of spoken language. Just like speech, texting is not codified and thus highly variable. Just like vernacular speech, texting is often highly informal. Just like speech, texting follows a set of implicit social and linguistic norms (Tagliamonte and Denis, 2008;

Tagliamonte, 2014; Tagliamonte, Uscher and Kwok, 2016). These features of text messages account for many of the major findings of present study.

${ }^{18}$ In Quebec French, previous studies have shown that many borrowed English verbs are morphologicaly integrated (Vinet 1996, Poplack, 2018). Therefore in this example we consider the borrowed form 'call' as present tense, potentially in variation with je vais te caller or eventually je te callerai. 
First, we have seen high rates of the Present variant, which relies on the interactional context of proximity. Our results show a much higher rate of Present (over 40\%) than had been reported in previous studies based on semidirected interviews (under 10\%). Gudmestad et al.'s (2018) study of FTR in conversations show that informal conversations provide more of such cues, which accounts for the higher rate $(26 \%)$ of the Present variant in their study ${ }^{19}$. Given that the interpretation of the Futurate Present relies on contextual cues, whether implicit or explicit, higher rates of the Present variant are expected to be found in conversations.

Second, the rate of use of the Analytic variant over the Synthetic variant sets text messages apart from written Standard French, and more in keeping with oral corpora. When we exclude the Present variant and compare the rates of Synthetic Future in natural conversations to the rate of Synthetic Future in semi-directed interviews, we find very similar rates, both in France and in Canada. For Hexagonal French, Edmonds et al. (2017) report a rate of 34\% Synthetic in conversations, which is similar to the rate of $41 \%$ reported in Roberts' (2012) study based on semi-directed interviews. Similarly, for Québec French, the rate found in the present study of text messages (37\%) is also close

${ }^{19}$ Edmonds et al.'s (2017) study of FTR in L2 conversations report an even higher rate of the Present variant (37\%) from non-native speakers in the same context. 
to that found in Poplack and Turpin's (1999) study (22\%), but very different from the rates above 95\% found in Québec newpapers (Lesage and Gagnon, 1992).

Finally, we have seen that text messages are subject to dialectal variation, another feature which associates it with informal speech. We have shown that dialectal variation can be observed in the different rates and constraints in the use of the Analytic vs. Synthetic Future. The first person singular is particularly prone to encode dialectal features of the FTR variable. We mentioned in section 1 that the use of $\underline{v}$ [ve] for vais [ve], and expliquerè [عksplikre] for expliquerai [eksplikre] in example (1) illustrate the neutralization of e/c in Belgian French. The use of va [va] for vais in example (8a) and ma $[\mathrm{ma}]$ in (8b) for je vais illustrate the vas/mas/vais variable, charasteristic of Québec French.

(8) a. Jtm itoo! A betot..jva te txter mais on na fini el souper. Je t'aime aussi. À bientôt. Je vais te texter quand on a fini le souper. 'I love you too. See you soon... I'll text you when we're finished dinner.'

(QC user_112332)

b. Lol my god t une brute, faut ajouter une source a Virginie, si tu travail en fin dsemaine ma tle montrer

Lol my god T'es une brute, faut ajouter une source à Virginie, si tu travailles en fin de semaine, je vais te le montrer.

'Lol my god you-are a brute, you must add a source to Virginie, if you work this weekend I'll show you.'

$\underline{(\mathrm{QC}, \text { user 110270) }}$ 


\section{Conclusion}

This paper has provided a comparative study of the expression of Future Temporal Reference in text messages in two varieties of French. Three variants were considered: the Futurate Present, the Synthetic Future and the Analytic Future. The results of the multivariate analyses show that the two communities (Belgium and Québec) display very similar grammars in the use of the Futurate Present. This variant is found at comparable rates in the two varieties.

Moreover, the factors conditioning the use of the Futurate Present are strikingly alike in both varieties: morphological Verb Type, Adverbial Specification, and Contingency are good predictors, while Polarity and Temporal Distance are not significant. Our results further reveal that dialectal variation is limited to the choice between the Synthetic and the Analytic Future. The factors conditioning the choice of the Synthetic Future vs. the Analytic Future show distinct configurations: 1- while Polarity is the strongest factor in Québec, it is not significant in Belgium; 2- non-specific adverbs strongly favour the presence of the Synthetic Future in Belgium, but not in Québec. However, Temporal Distance is significant in both varieties, with the Analytic Future being favoured by proximal future events. This last result tends to show that the Analytic and Synthetic Futures are not strictly semantically equivalent. However, the fact that these two forms are not mutually exclusive and heavily 
subject to dialectal variation indicate that the distinction is nevertheless blurry, which argues in favour of the weak equivalence approach adopted in this paper. Finally, both varieties are sensitive to the morphological complexity of verbal paradigms: the most irregular verbs (être, avoir, modals) favour the Synthetic variant, while other regular and irregular verbs favour the Analytic Future. The present study contributes to research on future-time expression in French at the empirical, methodological and theoretical levels. At the empirical level, we add to the large body of literature on FTR in French a variationist study that includes the Futurate Present. Second, we consider a type of corpus that has seldom been studied in variationist research, which is often based on semi-directed interviews, rather than naturally-occurring conversations. The inclusion of text message corpora adds a new dimension to the analysis of the variable. Our study also contributes to the developing field of inquiry on the morphosyntax of text messages in French (Stark, 2011, 2012; Blondeau et al., 2014; Labeau, 2014, among others), and documents the hybridity of this form of communication. On the one hand, text messages are not exempt from the influence of written French, as shown by the use of Synthetic Future forms in affirmative sentences in the Québec corpus, where the range of 44 is much narrower than in sociolinguistic interviews (Blondeau, 2006 reports a range of 56 in the 1971 and 1984 corpora, and a range of 63 in the 1995 corpus). On the 
other hand, our results show patterns of use that are more in line with oralconversational corpora as reflected by the dialectal variation observed. Third, we provide a comparative study of two dialects providing a deeper understanding of the constant vs. variable properties of FTR in French. Finally, while Québec French has been the focus of numerous variationist studies over the last 50 years, Belgian French has been relatively neglected by sociolinguists. The present study thus contributes to documenting the specific features of that largely understudied variety.

In terms of methods, many studies have excluded the Futurate Present in the analysis on the grounds that this variant is too rare. A posteriori, our study provides additional, more principled motivations for the possible exclusion of this variant from the analysis. Even studies which include the Futurate Present in the analysis need to distinguish between two variable contexts. Context 1 : Covert T vs Overt T. Context 2: Synthetic vs Analytic morphological future. Moreover, the choice between Covert $\mathrm{T}$ vs Overt $\mathrm{T}$ is subject to different sets of constraints than the choice between the Synthetic vs. Analytic future. While the former appears to be stable over time and varieties, the latter is subject to dialectal and diachronic variation. Consequently, studies concerned with dialectal and diachronic variation could focus on the linguistic factors constraining the choice between the Synthetic vs the Analytic Future, without 
the inclusion of the Futurate Present in the analysis. However, the inclusion of this variant would be crucial for studies concerned with the role of context in the identification of Covert $\mathrm{T}$, or with the contribution of pragmatic factors. Ultimately, the decision to include the Futurate Present or not in the set of variants included in the envelope of variation should not only be determined by the frequency of the variants, but also the subject of inquiry.

Finally, our study has theoretical consequences for our understanding of Labov's Principle of Accountability. This principle requires that the analyst examine all relevant forms in the system of grammar under investigation. This is often understood as an indication to include all variants, including zero variants, as long as the zero variants are semantically equivalent, or weakly equivalent, to the overt variants. The present study argues that the decision to include a given variant or not in the analysis (in the set of variants) also depends on the linguistically defined variable context which is relevant to the research question.

Word count: 8,451

\section{References}

Aaron, J. (2010). Pushing the envelope: looking beyond the variable context. Language Variation and Change, 22: 1.1-36. 
Abouda, L. and Skrovec, M. (2015). Du rapport entre formes synthétique et analytique du futur. Étude de la variable modale dans un corpus oral micro-diachronique. Revue de Sémantique et Pragmatique, 38: 33-57.

Blake, R. (1997). Defining the envelope of linguistic variation: The case of 'don't count' forms in the copula analysis of African American Vernacular English. Language Variation and Change, 9: 57-79.

Blondeau, H. (2006). La trajectoire de l'emploi du futur chez une cohorte de Montréalais francophones entre 1971 et 1975. Revue de l'Université de Moncton 37:73-98.

Blondeau, H., \& Labeau, E. (2016). La référence temporelle au futur dans les bulletins météo en France et au Québec : regard variationniste sur l'oral préparé. Revue canadienne de linguistique / Canadian Journal of Linguistics, 61(3):240-258.

Blondeau, H., Tremblay, M., \& Drouin, P. (2014). Hybridité et variation dans les SMS: Le corpus Texto4Science et l'oralité en français montréalais. Revue canadienne de linguistique / Canadian Journal of Linguistics, 59(1):137-166.

Chevalier, G. (1996). L'emploi des formes du futur dans le parler acadien du sud-est du Nouveau-Brunswick. In: L. Dubois and A. Boudreau (eds), 
Les Acadiens et leur(s) langue(s) : quand le français est minoritaire.

Moncton: CRLA, Université de Moncton, pp. 75-89.

Chomsky, N. (1995). The Minimalist Program. Cambridge: MIT Press.

Comeau, P. (2011). A Window on the Past, a Move toward the Future:

Sociolinguistic and Formal Perspectives on Variation in Acadian

French. Doctoral dissertation, York University, Toronto.

Comeau, P. (2015). Vestiges from the grammaticalization path : The expression of future temporal reference in Acadian French. Journal of French Language Studies, 25(3) :339-365.

Comeau, P. (2016). An extension of the comparative sociolinguistics approach for sociosyntax: Comparing a single linguistic constraint across multiple sociolinguistic variables. Linguistic Variation, 16 (2) :183-220.

Comeau, P. and Villeneuve, A.-J. (2014). Contrasting constraints in future temporal reference. Presentation at NWAV 43. URL: http://www.nwav43.illinois.edu/program/documents/ComeauVilleneuve-longabstract.pdf, retrieved?

Cougnon, L.-A. and François, T. (2010). Quelques contributions de statistiques à l'analyse sociolinguistique d'un corpus de SMS. In: S. Bolasco et al. (eds), Statistical Analysis of Textual Data. Proceedings of $10^{\text {th }}$ 
International Conference JADT, 9-11 juin 2010. Sapienza University of Rome: 1: 619-630.

Crystal, D. (2011). Internet Linguistics. London: Routledge.

Deshaies, D. and Laforge, È. (1981). Le futur simple et le futur proche dans le français parlé dans la ville de Québec. Langues et Linguistique, 7: 2337.

Dines, E. R. (1980). Variation in discourse "and stuff like that". Language in Society, 9: 13-31.

Edmonds, A., Gudmestad, A. and Donaldson, B. (2017). A concept-oriented analysis of future-time reference in native and near-native Hexagonal French. Journal of French Language Studies, 27: (3)381-404. doi:10.1017/S0959269516000259

Emirkanian, L. and Sankoff, D. (1985). Le futur simple et le futur proche. In: M. Lemieux and H. Cedergren (eds), Les tendances dynamiques du français parlé à Montréal. Vol 1. Québec: Office de la langue française, pp. 189-204.

Fairon, C., Klein, J.-R. and Paumier, S. (2006). SMS pour la science. Corpus de 30.000 SMS et logiciel de Consultation. Cahiers du Cental 3.2. Presses Universitaires de Louvain. 
Fleury, S. and Branca-Rosoff, S. (2010). Une expérience de collaboration entre linguistique et spécialiste de TAL : L'exploitation du corpus CFPP 2000 en vue d'un travail sur l'alternance Futur simple Futur périphrastique. Cahiers AFLS, 16(1):63-98.

Grimm, R. D. (2010). A real-time study of future temporal reference in spoken Ontarian French. University of. Pennsylvania Working Papers in Linguistics, 16(2) :83-92.

Grimm, R. D. (2015). Grammatical variation and change in spoken Ontario French: The subjunctive mood and future temporal reference. Doctoral dissertation, York University.

Grimm, R. and Nadasdi, T. (2011). The future of Ontario French. Journal of French Language Studies, 21: 173-189.

Gudmestad, A., Edmonds, A., Donaldson, B. and Carmichael, K. (2018). On the role of the present indicative in variable future-time reference in Hexagonal French. Canadian Journal of Linguistics/Revue Canadienne De Linguistique, 63(1): 42-69. doi:10.1017/cnj.2017.41

Hansen, A. B. and Strudsolm, E. (2006). Morphological and periphrastic future in French and Italian spoken language: parallel tendencies? In: H. L. Andersen, M. Birkelund and M.-B.-M. Hansen (eds), La linguistique au coeur: valence verbale, 
grammaticalisation et corpus: mélanges offerts à Lene Schosler

à l'occasion de son 60e anniversaire. Odense: Syddansk

Universitetsforlag, pp. 189-218.

Jeanjean, C. (1988). Le futur simple et le futur périphrastique en français parlé.

In: C. Blanche-Benveniste, A. Churvel and M. Gross (eds), Grammaire et histoire de la grammaire. Hommage à la mémoire de Jean Stefanini. Provence: L’Université de Provence pp. 235-257.

Kanwit, M. (2017). What we gain by combining variationist and conceptoriented approaches: The case of acquiring Spanish future-time expression. Language Learning, 67, 461-498.

King, R. and Nadasdi, T. (2003). Back to the Future in Acadian French. Journal of French Language Studies, 13(3) :323-337.

Labeau, E. (2014). Quand l'analytique se fait synthétique: les formes verbales périphrastiques dans le texto', Studii de lingvistica 4 :131-144.

Labov, W. (1972). Sociolinguistic Patterns. Philadelphia: University of Pennsylvania Press.

Labov, W. (1978). Where does a sociolinguistic variable stop? A response to Beatriz Lavandera. Working Papers in Sociolinguistics, 44: 6-19.

Labov, W. (2017). Some Parallels, accidental and expected. Canadian Journal of Linguistics/Revue canadienne de linguistique, 62(4) : 519-524. 
Langlais, P. and Drouin, P. (2012). Texto4Science : A Quebec French database of annotated text messages. Linguisticae investigationes, 35 :237-259.

Langlais, P., Drouin, P., Paulus, A., Rompré Brodeur, E. and Cottin, F. (2012). Texto4Science: a Quebec French Database of Annotated Short Text Messages. Proceedings, LREC, Istanbul, pp.1047-54.

Lavandera, B. (1978). Where does a sociolinguistic variable stop? Working Papers in Sociolinguistics, 40 :6-19.

Leblanc, C. (2007) Le futur périprastique dans le français parlé : une question d'habitude. Thèse de doctorat, Université d'Ottawa.

Leblanc, C. (2009). ALLER parfois, PRÉSENT souvent : l'expression de l'habituel en français parlé. Le français d'ici : études linguistiques et sociolinguistiques sur la variation du français au Québec et en Ontario. F. Martineau, R. Mougeon, T. Nadasdi and M. Tremblay (eds.) Toronto: Éditions du GREF, coll. Theoria no 13:91-125.

Lesage, R. (1991). Notes sur l'emploi du présent à valeur de futur dans les quotidiens québécois. Revue québécoise de linguistique théorique et appliquée, 10: 117-131.

Lesage, R. and Gagnon, S. (1992). Futur simple et futur périphrastique dans la presse québécoise. In: A. Crochetière, J.-C. Boulanger and C. Ouellon 
(eds), Les langues menacées : actes du XVe Congrès international des linguistes. Sainte-Foy: Les Presses de l’Université Laval, pp. 367-370. Lindschouw, Jan (2011) : «L'évolution du système du futur du moyen français au français moderne : la réorganisation comme un cas de régrammation ». Revue de Linguistique Romane 297-298, pp. 51-97

Lindschouw, Jan (2013) : « The marking of person deixis in the French future system - a diachronic approach », in Jeppesen Kragh, K. \& J. Lindschouw (Eds) : Deixis and Pronouns in Romance Languages. Amsterdam/Philadelphia : Benjamins, pp. 227-249.

Mougeon, R. and Beniak, É. (1991). Linguistic Consequences of Language Contact and Restriction: The Case of French in Ontario. Oxford: Clarendon Press.

Poplack, Shana. 2018. Borrowing: Loanwords in the Speech Community and in the Grammar. Oxford: Oxford University Press.

Poplack, S. and Dion, N. (2009). Prescription vs. praxis: The evolution of future reference in French. Language, 85: 557-587.

Poplack, S. and Tagliamonte, S. (1989). There is no tense like the present: Verbal -s inflection in early Black English. Language Variation and Change, 1(1) :47-84. 
Poplack, S. and Tagliamonte, S. (2001). African American English in the Diaspora. Oxford and Maiden, MA: Blackwell.

Poplack, S. and Turpin, D. (1999). Does the Futur have a future in (Canadian) French? Probus, 11(1) :133-164.

Rand, D. and Sankoff, D. (1990). GoldVarb: a variable rule application for Macintosh. Montreal, Canada: Centre de recherches mathématiques, Université de Montréal.

Roberts, N. S. (2012). Future Temporal Reference in Hexagonal French. University of Pennsylvania Working Papers in Linguistics, 18(2) :97106.

Roberts, N. S. (2014). A Sociolinguistic Study of Grammatical Variation in Martinique French. Unpublished PhD Dissertation, Newcastle University.

Roberts, N. S. (2016). The future of Martinique French: The role of random effects on the variable expression of futurity. Canadian Journal of Linguistics, 61(3) :240-258.

Sankoff, D., Tagliamonte, S. and Smith, E. (2005). Goldvarb X: A variable rule application for Macintosh and Windows. URL:http://recombcg.uottawa.ca/lab/software.html 
Sankoff, D. and Thibault, P. (1981). Weak complementarity: tense and aspect in Montreal French. In: B.B. Johns and D.R. Strong (eds), Syntactic Change. Natural Language Studies, 25 :205-216.

Sankoff, G. (1986 [1973]). Above and beyond phonology in variable rules. In: The Social Life of Language. Philadelphia: University of Pennsylvania Press, pp. 81-93. Originally published in: C.J. N. Bailey and R. Shuy (eds), New Ways of Analyzing Variation in English. Washington DC: Georgetown University Press, pp. 44-61.

Sankoff, G., Evans Wagner, S. and Jensen, L. (2012). The long tail of language Change: Québécois French futures in real time. University of Pennsylvania Working Papers in Linguistics, 18(2) :83-92.

Söll, L. (1983). De la concurrence du futur simple et du futur proche en français moderne. In: F.-J. Hausmann (ed), Etudes de grammaire française descriptive. Heidelberg: Julius Groos Verlag, pp. 16-24.

Stark, É. (2011). La morphosyntaxe dans les SMS suisses francophones : Le marquage de l'accord sujet - verbe conjugué. Linguistik, 48 :35-47.

Stark, É. (2012). Negation marking in French text messages. In: Lingvisticae Ingvestigationes (35): SMS Communication: A linguistic approach. Under direction of L. Cougnon and C. Fairon, pp. 341-366. 
Stelling, L. (2008). Morphosyntactic Variation and Language Shift in Two Franco-American Communities. Unpublished doctoral dissertation, University at Albany, State University of New York, Albany, New York.

Tagliamonte, S. (2002). Comparative sociolinguistics. In: J. K. Chambers, P. Trudgill and N. Schilling-Estes (eds), The Handbook of Language Variation and Change. Oxford and Malden, MA: Blackwell, pp. 729763.

Tagliamonte, S. (2014). Situating media influence in sociolinguistic context. Journal of Sociolinguistics, 18(2) :223-232.

Tagliamonte, S. and Denis, D. (2008). Linguistic ruin? LOL! Instant messaging and teen language. American Speech, 83(1): 3-34.

Tagliamonte, S., in collaboration with D. Uscher, L. Kwok, and students from HUM199Y, 2009-2010. (2016). So sick or so cool? The language of youth on the internet. Language in Society, 45(1): 1-32.

Tremblay, M. (submitted) Le texto: une pratique langagière distincte? Manuscript under review.

Villeneuve, A.-J. and Comeau, P. (2016). Breaking down temporal distance in a Continental French variety: Future Temporal reference in Vimeu. Canadian Journal of Linguistics, 61(3): 314-336. 
Vinet, M.-T. (1996) Lexique, emprunts et invariants : une analyse théoriquedes anglicismes en français du Québec. Revue québécoise de linguistique 24 (2) : 165-181.

Wagner, S. E. and Sankoff, G. (2011). Age-grading in the Montréal French inflected future. Language Variation and Change, 23 :275-313.

Wales, M. L. (1983). The semantic distribution of aller + infinitive and the future tense in spoken French. General Linguistics, 23: 19-28.

Wales, M. L. (2002). The relative frequency of the synthetic and composite futures in the newspaper Ouest-France and some observations on distribution. Journal of French Language Studies, 12: 73-93.

Walker, J. (2013). Variation Analysis. In: R. J. Podesva and D. Sharma (eds), Research Methods in Linguistics. Cambridge: Cambridge University Press, pp. 440-459.

Waugh, L. and Bahloul, M. (1996). La différence entre le futur simple et le futur périphrastique dans le discours journalistique. Modèles Linguistiques, 17: $19-36$.

Zimmer, D. (1994). « Ça va tu marcher, ça marchera tu pas, je le sais pas » (71:15). Le futur simple et le futur périphrastique dans le français parlé à Montréal. Langues et linguistique, 20: 213-226. 